\title{
Disaster management and generational complacency: five crucial lessons
}

\author{
E. G. Bianchi \\ Group Manager, Noel Arnold \& Associates, Australia
}

\begin{abstract}
The World has suffered major disasters in the last 24 months. What have we learnt from natural disasters in the past, and what can we do differently in the management of critical disasters to minimise their impact on life, property and the environment? From a realistic and practical perspective, this paper will challenge conference attendees to consider the relationship between historical events and generational complacency, a learning from history, in measures to manage disasters, from devastating floods (which regularly flood the major Australian state of Queensland and city of Brisbane), to bushfires in 2009 which killed almost 200 hundred people.

Australia has a unique history of natural disasters, ranging from extremes in high temperature, to floods and cyclones. The impacts of these are highly destructive, and Australia, like some countries, has partly learnt from the past, and has developed extensive capability and strategic approaches for pre-empting and managing such events, lessons which have world wide application and benefit. Techniques for pre-planning as well as dealing with the aftermath of a disaster are critical in ensuring that the confidence of the public is restored and/or maintained to ensure the effective "normalisation" of communities post the disaster.

A simple risk management philosophy will be proposed to define the 5 lessons to manage such disasters, which all too often are a victim of generational complacency resulting in ineffective emergency management.

The paper will provide a summary of mistakes from the past, Australia's current initiatives and techniques in addressing emergency needs, including prevention, communication, response and recovery. Conference delegates will
\end{abstract}


gain a unique and valuable insight into learning from the past, and the pro-active disaster management processes and techniques which must be formalised and enabled into the future.

Keywords: risk, fire, disaster, flood, resilience, prevention, Australia, system, generation, complacency.

\section{Introduction}

The management of past disasters in comparison to the approaches of today, has provided governments, authorities and community groups, including crisis and critical incident management personnel, a wealth of knowledge and data. One must ask, with an abundance of information and technologies that we still see major incidents being ineffectively managed and poorly planned for, placing huge social, physical and economic burdens on countries. This paper will challenge global thought patterns and community expectations to learn from history, and explore how generational change and complacency has played a contributing factor to ineffective disaster management.

Major natural disasters in Australia are generally predictable, however despite the best intentions of most governments and community groups, have been poorly managed and controlled. Worldwide, we continue to repeat the errors of the past. The five crucial lessons that need to be understood and communicated to current and future generations are as follows:

Lesson 1: Learn from the past - History repeats

Lesson 2: Evaluate the Impact of Incidents

Lesson 3: Legislate Change - Policy and Governance

Lesson 4: Design and Communication

Lesson 5: Future Proofing

This paper will focus on a number of recent and past natural disasters in Australia, which will provide the framework for the above lessons.

\section{Lesson one: learn from the past: history repeats}

Australia, like many countries around the world has a unique natural risk profile, being that it is susceptible to extreme heat, droughts, fires, cyclones and floods. As a result the country experiences extremes of weather and environmental events. Major fire and flood events continue to affect Australia. In the last two years Australia has once again suffered major floods and fires, events which are cyclic in nature and are generally predictable. Once again, these events have proven that there is one very important lesson that it is not being learnt (in Australia and globally for that matter) - learn from the mistakes of the past and do not fall not into the trap of generational complacency. Subsequently allowing the effects of time and years post disaster to reduce drive, engagement and resourcing in an attempt to implement preventative risk controls. Risk management methodologies need to address generational complacency as a real contributory factor. 


\subsection{Floods}

The area of Brisbane located in Queensland has experienced major flooding over the centuries. Recent floods have occurred in 1974 and 2011 both similar in nature, with economic impact measured at approximately 6 billion dollars [1] each (refer Figures 1 to 4). In 1974 the lesson learnt was the need to mitigate the damage of future floods, and as a result the Wivenhoe Dam was built. The dam was completed in 1984 and located approximately $80 \mathrm{~km}$ upstream from the City of Brisbane.

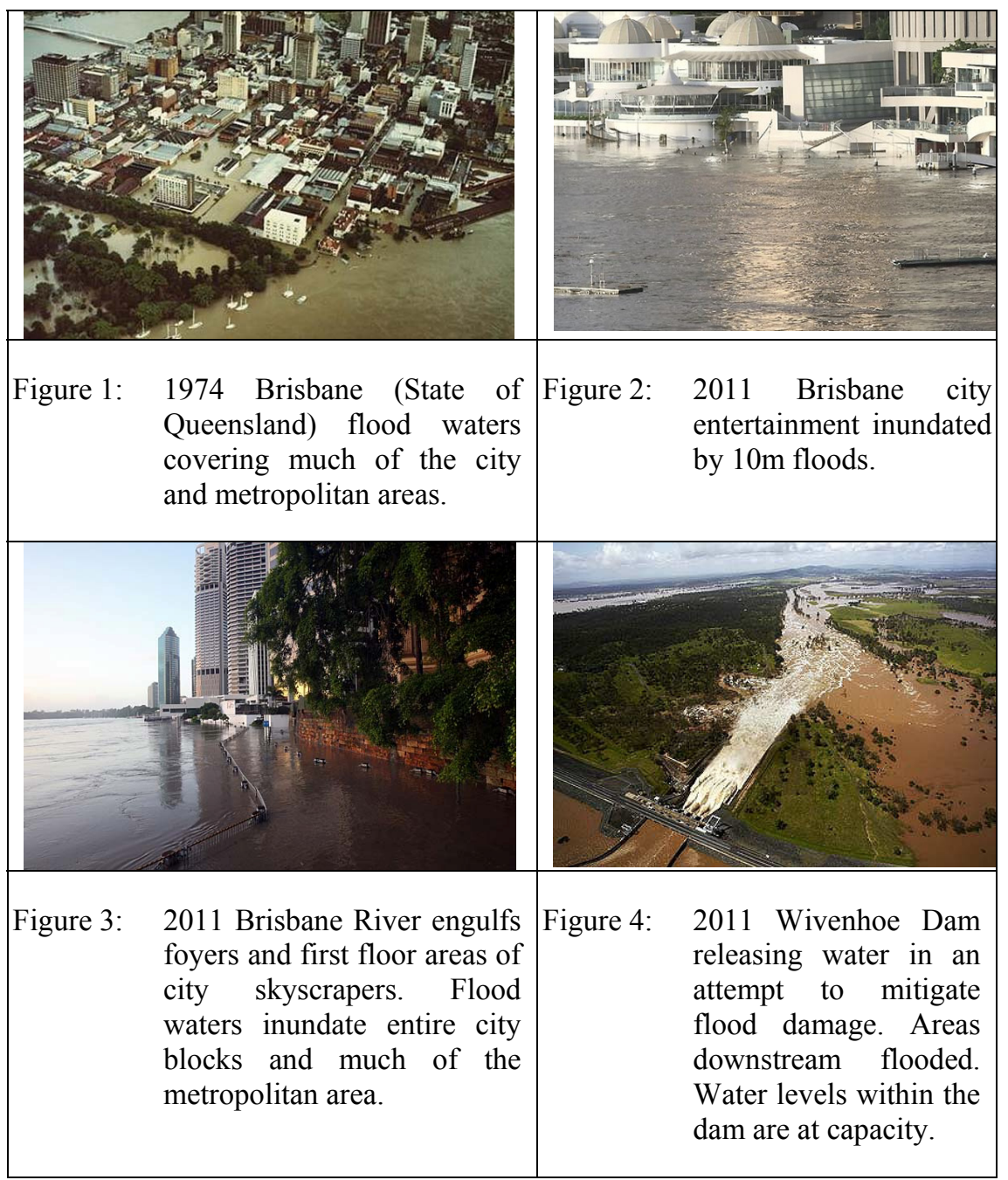

(Photos: Fairfax digital newspapers, State Library of Queensland, and Brisbane Times.) 
In 2007 the Wivenhoe Dam was at 17\% capacity. In 2011 it was at 190\% capacity [2] (refer Figure 4). A massive storm system and rain deluge over a few weeks, influenced by a strong La Nina, dramatically broke the drought in Queensland which had lasted for many years. This dam was to play a major role in controlling the massive water influx into the Brisbane river catchment area and surrounds, but its effectiveness to do so was compromised due to a failure of Authorities to act on Bureau of Meteorology advice to release water from the dam early. A number of questions were posed to why the government and authorities not act early enough?:

- Was it due to generational complacency and minimal first hand experience or memory of the floods that occurred approximately 35 years earlier?

- Was there a failure to effectively communicate the need to release water?

- Was the State's emergency crisis preparedness not really ready?

- Fear of public reaction to release so much water when the state of Queensland was on water usage restrictions?

- Was it not known that a full dam holds no more water!

The Bureau of Meteorology has maintained a detailed history and trend of flood events in Queensland [2]. The impacts are predictable if measures are not taken to reduce the effect of these natural disasters. The answers to the above questions are currently being investigated by government enquiries and commissions. There is however an element of generational complacency and in particular of a failure to learn from the past, knowing that the dam was designed to mitigate flood damage, which required early intervention.

\subsection{Fire}

Fires within Australia are common and part of our landscape and history as is evident from the fires of 1926, 1939, 1967, 1983 and 2009.

These fires and in particular the events in 1983 [3] and 2009, were almost identical in nature, spaced almost 30 years apart, as per the Brisbane floods. The photos G and H show a very similar theme. The lessons of 1983 and 2009 were not implemented and despite various enquiries and investigations into the fires, the following prevailed:

- $\quad$ Fuel loads were not reduced in forest, urban and residential areas;

- Buffer zones and clearances around properties were not adhered to nor maintained;

- Design codes and recommendations for residential properties in fire prone areas were not effectively addressed and implemented;

- Realistic and well communicated emergency plans were weak and not effectively activated; and 
- The use of animal stock to help reduce fuel loads and forest undergrowth (as had occurred for over a hundred years prior), was prevented due to vocal conservative groups.

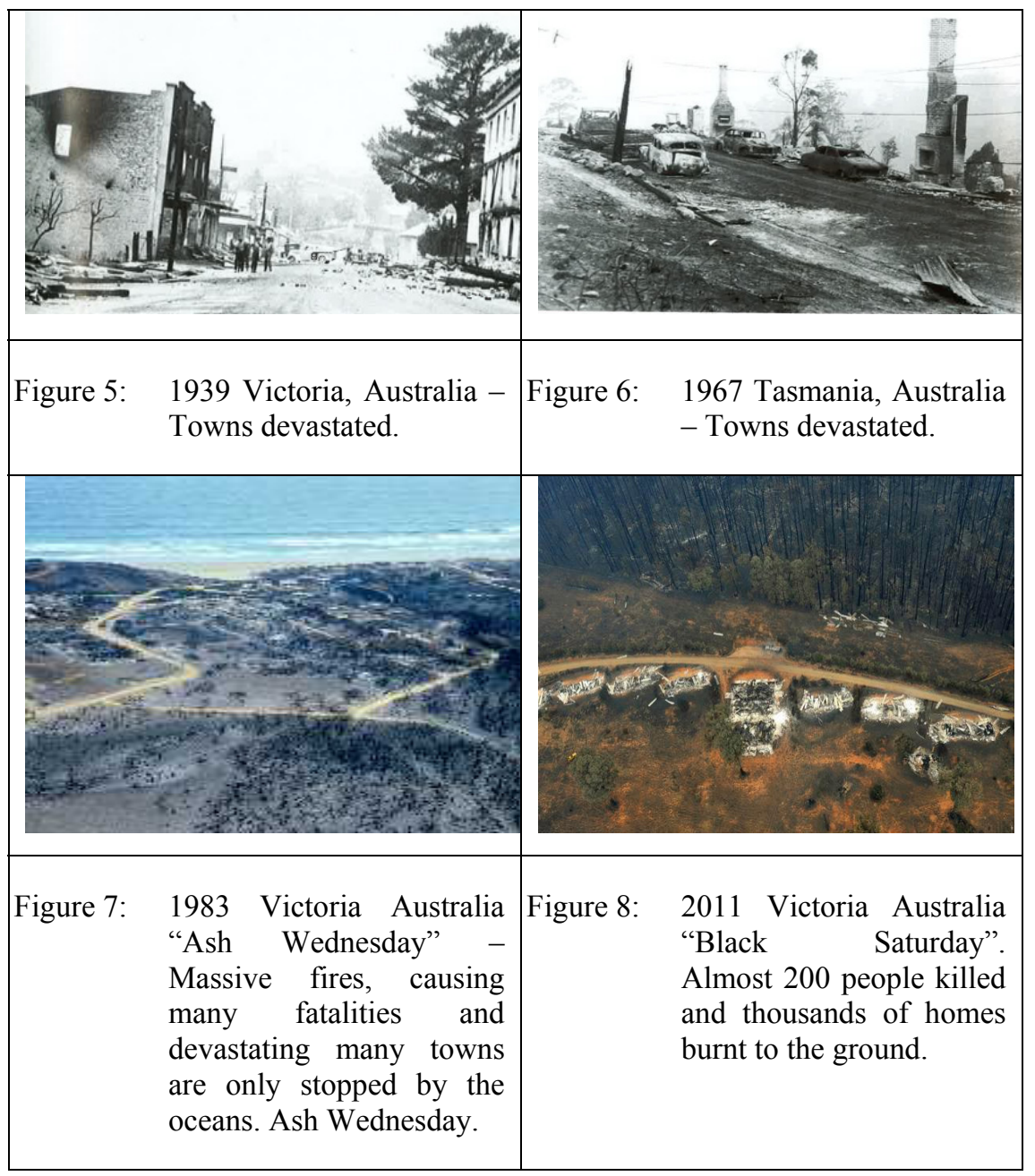

(Photos: "Burn” by Paul Collins, and Dept. Sustainability and Environment.)

\subsection{Generational complacency}

The impact from of disasters has evolved over time from a local to a national issue to one where global live coverage is the norm, with potential impacts on financial markets and global welfare organisations. Countries are not learning from the past, particularly with the technology today that enables greater scrutiny with widespread global media coverage. Complacency, generational change, 
memory, and bureaucracy have all played a part. The CSIRO [4, 5] and many other reputable research organisations in Australia have known for a long time that fires, floods and natural disasters are not unpredictable and are not a matter of "if" they occur, but "when" they will occur.

Very quickly the world is realising that with the aid of globalisation, live TV coverage, internet and communications technology, natural disasters are telecast live within homes all around the world. This has immediate social, economic and political impact, unlike in the past, and can have catastrophic consequences. The common theme that stems from Australian natural disasters, and indeed global natural disasters, is that pre-1980's, there were limited scrutinised approaches to the management of the events. The current processes attempt to apply pro-active management systems to control the risk. There is also greater legislative impetus on countries to manage these events, with building and design changes, and legislative change.

The frequency of the Australian natural disasters is on average 30 years apart, coincidentally a generation apart. What has been learnt to manage these events and their impact on society? Despite a concerted effort to address the root cause immediately following the events, and after the "dust" had settled, the initial impact of the tragedy had worn off, editorials in the newspapers and headlines had disappeared, the urgency and need to drive change had slowed down. Governments and authorities change, and new faces and generations are left to realise this change. A common failure is not learning from the past and not factoring in generational change in the risk matrix.

\section{Lesson two: evaluate the impact of incidents}

Consistent with criteria defined in ISO31000 Risk Management, one must clearly identify the areas of vulnerability and/or exposure in any disaster management plan. When looking at natural disasters, one can identify 5 areas of exposure and impact of an incident as follows:

- Physical;

- Social;

- Political;

- Environmental; and

- Economic.

The challenge in a pro-active risk management program is the effective quantification of the impact of a major disaster, and today this is often seen live globally (as seen in recent events including the recent earthquakes and Tsunami's in Japan and Thailand). In an effort to provide a broad summary of the 5 key parameters, the following Table has been developed which shows the impact on the various criteria and the comparative effect on a time scale. As can be seen from Table 1 below, natural disasters are providing mechanisms and knowledge to effectively manage events into the future with key initiatives going forward. The expectations of the community in the future will be closely aligned to risk elimination and mitigation. 
Table 1: Chronological natural disaster impacts.

\begin{tabular}{|c|c|c|c|}
\hline \multirow[t]{2}{*}{ Impact } & Historic & Current & Predicted \\
\hline & Pre-1980 & $1980-2011$ & 2011-2040 \\
\hline Physical & $\begin{array}{l}\text { Property damage. } \\
\text { Temporary local } \\
\text { reactive media } \\
\text { coverage. } \\
\text { Minimal evaluation of } \\
\text { social/psychological } \\
\text { impact on affected } \\
\text { people. }\end{array}$ & $\begin{array}{c}\text { Quantification of } \\
\text { infrastructure damage. } \\
\text { Risk profiling. } \\
\text { Live global pictures } \\
\text { and video. } \\
\text { Personal and community } \\
\text { group accounts of } \\
\text { negative aspects of } \\
\text { physical impact. }\end{array}$ & $\begin{array}{l}\text { Physical impact pre- } \\
\text { empted. } \\
\text { Construction plans in } \\
\text { place to re-build } \\
\text { appropriately. }\end{array}$ \\
\hline Social & $\begin{array}{c}\text { Impact on } \\
\text { communities, culture, } \\
\text { history not fully } \\
\text { quantified limited, and } \\
\text { mostly lost. }\end{array}$ & $\begin{array}{c}\text { Impact on social } \\
\text { wellbeing controlled and } \\
\text { measures taken to control } \\
\text { negative impacts via } \\
\text { counselling, forums, } \\
\text { global support. } \\
\text { Indigenous impact a } \\
\text { consideration. }\end{array}$ & $\begin{array}{l}\text { Prompt and pre- } \\
\text { emptive intervention } \\
\text { Aspects of social } \\
\text { impact that are } \\
\text { critical to } \\
\text { maintaining positive } \\
\text { culture and drive } \\
\text { maintained and } \\
\text { encouraged. }\end{array}$ \\
\hline Political & $\begin{array}{l}\text { Reactive response to } \\
\text { disasters. Leadership } \\
\text { minimal, and mostly } \\
\text { taken up by emergency } \\
\text { response personnel. } \\
\text { Criticism of political } \\
\text { parties lively but } \\
\text { limited in impact } \\
\text { owing to lack of } \\
\text { importance placed on } \\
\text { pro-active risk } \\
\text { management }\end{array}$ & $\begin{array}{l}\text { Leadership taken from } \\
\text { political heads of } \\
\text { government, supported by } \\
\text { emergency personnel } \\
\text { and advisors. } \\
\text { Potential for responsible } \\
\text { parties to be liable. } \\
\text { Community expectation of } \\
\text { government heightened } \\
\text { with leaders being judged } \\
\text { and critiqued. }\end{array}$ & $\begin{array}{c}\text { Leadership is } \\
\text { expected of their } \\
\text { politicians. } \\
\text { Litigation, whilst not } \\
\text { eliminated is } \\
\text { minimal, as due } \\
\text { diligence and } \\
\text { pre-emptive risk } \\
\text { management policies } \\
\text { are realised. } \\
\text { Politicians will drive } \\
\text { change. }\end{array}$ \\
\hline Economic & $\begin{array}{l}\text { Minimal knowledge on } \\
\text { how to effective } \\
\text { quantify. } \\
\text { Actual impact } \$ \\
\text { estimated, but the final } \\
\text { costs are rarely known. }\end{array}$ & $\begin{array}{c}\text { Economic cost considered } \\
\text { in global spheres, } \\
\text { impacting on share } \\
\text { markets. } \\
\text { Rebuild costs are } \\
\text { quantified. } \\
\text { Insurance is generally } \\
\text { in place. } \\
\text { Global assistance usually } \\
\text { reactive. } \\
\end{array}$ & $\begin{array}{l}\text { Economic evaluation } \\
\text { is the norm. Global } \\
\text { assistance packages } \\
\text { are pre-empted. } \\
\text { Insurance companies } \\
\text { assign to global } \\
\text { catastrophic } \\
\text { insurance. }\end{array}$ \\
\hline \multirow[t]{2}{*}{ Impact } & Historic & Current & Predicted \\
\hline & Pre-1980 & $1980-2011$ & 2011-2040 \\
\hline Environmental & $\begin{array}{l}\text { Minimal consideration } \\
\text { of environmental } \\
\text { impact. }\end{array}$ & $\begin{array}{c}\text { Environmental } \\
\text { considerations are part of } \\
\text { pro-active risk } \\
\text { management plan. } \\
\text { True impact on } \\
\text { environment is } \\
\text { critiqued by vocal } \\
\text { environmental groups. }\end{array}$ & $\begin{array}{l}\text { Impact is known and } \\
\text { effective measures } \\
\text { promptly } \\
\text { implemented to } \\
\text { manage the } \\
\text { environment in a } \\
\text { sustainable way. }\end{array}$ \\
\hline
\end{tabular}




\section{Lesson three: legislate change - policy and governance}

The need to legislate compliance with new initiatives and lessons learnt from previous events is continually evolving; however their effectiveness is once again impacted by generational complacency to remember events, their route cause and to drive change. In 2003 the Council of Australian Governments (COAG) [5] 'Review of Natural Disaster Relief and Mitigation', recommended:

- National risk assessment of natural disaster prone areas;

- Improved community awareness and instruction on risk; and

- Improved land use planning and gathering the data to convince governments on real positive return on investment.

Whilst positive change is improving, the recent events in Australia (the widespread floods in Brisbane and devastating bushfires in Victoria) are classic examples of the failure to engender and value change. We still continue to build vulnerable homes in bushfire prone areas [6], and build commercial, residential properties and many 50 storey skyscrapers in areas that will flood again. We continue to stumble in achieving effective pro-active emergency preparedness and risk mitigation systems. What is even more alarming is the fact that the Queensland Government had not taken up its insurance to cover the loss of public assets in the event of a flood, in an attempt to save $\$ 50 \mathrm{~m}$ per annum in insurance cover [1]. This alone has almost made the state bankrupt, necessitating the creation of special taxes and levies imposed on all Australians.

The 1983 bushfires in Victoria have provided the drive to identify the need for state based disaster plans, with emergency management authorities all playing a key part. Red tape and bureaucracy have contributed to major failures in risk control and disaster preparedness, despite the best intentions of legislators since 1983 [7]. So what are we looking at in terms of legislating change? It is clear that ownership and endorsement of the need for change from our regulators and authorities is essential. Cultural change and generational engagement is needed.

\section{Lesson four: design and communication}

A necessary part of the legislative change is to put into effect the requirements of all the parameters impacting on engineering design and maintenance. Reforms are already occurring with regulatory obligations now placed on various contracting parties involved in planning and design. This includes:

- Obligations of designers, planners, builders and authorities;

- Business continuity and resilience plans; and

- Communication protocols for leaders and advisors including live telecommunications, web updates, disaster zone and mobile phone emergency warnings. 
The obligations are simple - ascertain your risk profile and minimise and/or eliminate that risk. This will ensure that due diligence obligations are met. It is important to do a "health" check of your risk management program and to test the program on a regular basis. If the system is not challenged, your emergency preparedness will be exposed, as demonstrated by recent events within Australia and globally. Engineering solutions are available to mitigate the impact of fires and floods, and it is worth noting that the design of residential properties in Brisbane and more broadly in the State of Queensland pre 1980's, were flood resistant, with open flow though areas below, and living areas above - very different to the way residential properties are built in these same areas today.

\section{Lesson five: future proofing}

If we continue to not adhere to the lessons learnt from the past, then exposure to major disasters impacting adversely (and unnecessarily) on our lives will continue. Being prepared for an undesirable but known event is an important step in ensuring that we are not being negligent in the exercise of powers and effective risk control. The question could be asked whether the authorities and powers at the time of the above events were negligent, or did they just fall into the trap of generational complacency. The answer to whether negligence played a part is still being played out in the courts today. The general trend into the future is the anticipation of events and pre-empting their occurrence, impact and their management [8]. The lesson will be to know how these events will impact on a country, how to effect risk minimisation and control, and to test plans and their resilience into the future, based on past, current and anticipated scenarios. If the answer to all of the following questions is yes, then one can say that they are well prepared to engage and mitigate impeding disasters:

- Is reliable data, including events of the past, and information accessible and being used by authorities to predict natural disasters?

- Have risk control and recovery plans been tested and proven effective for anticipated risk scenarios?

- Have responsibilities been allocated to authorities and tested in order to take effective control?

- Has infrastructure and building design risk evolved?

- Has generational complacency been addressed?

\section{Conclusion}

Heading towards 2040, approximately 30 years from now, we can expect the pre-empting and future proofing, as far as is practicable, of natural disasters. The key lessons for the management of future natural disasters are to learn from the past, apply the technology of today, implement real risk mitigation controls, and to beware of generational complacency. 
78 Environmental Health and Biomedicine

\section{References}

[1] Xenophon, N., Federal Senator, Editorial, 1 March 2011.

[2] Australian Geographic, Journal, Brisbane Floods, January 2011, www.australiangeographic.com.au.

[3] Department of Sustainability \& Environment, Victoria, Fire \& Other Emergencies, Bushfire History, Ash Wednesday Bushfire 1983, www.dse.vic.gov.au.

[4] Braganza, K. \& Church, J. A., Observations of Global \& Australian Climate, CSIRO, 2011.

[5] Lloyd, G., The Australian, Facing a Climate of Uncertainty, April 5, 2011.

[6] Cary, G. \& Lindenmayer, D. and Dovers, S., Australia Burning, Fire Ecology \& Policy Mgt Issues, pp. 34-105, 2008.

[7] Teague, B. \& McLeod, R. \& Pascoe, S., 2009 Victorian Bushfires Royal Commission, August 2009.

[8] Standards Australia, AS/NZS ISO 31000:2009, Risk Management Principles and Guidelines, Part 5, Process. 